УДК 378

13.00.00 Педагогические науки

\begin{abstract}
АКАДЕМИЧЕСКАЯ СРЕДА ВУЗА КАК ФАКТОР РЕАЛИЗАЦИИ МЕЖДУНАРОДНОЙ МОБИЛЬНОСТИ СТУДЕНТОВ

(из опыта международной деятельности СевероКавказского федерального университета)
\end{abstract}

\author{
Авакян Ани Самвеловна \\ ассистент \\ anichka35@mail.ru
}

Ломтева Татьяна Николаевна

д.пед.н., профессор, зав. кафедрой Романогерманского языкознания и межкультурной коммуникации

Северо-Кавказский федеральный университет,

Россия, г. Ставрополь

Статья посвящена рассмотрению опыта международной деятельности Северо-Кавказского федерального университета в рамках работы Ресурсного центра французского языка. В эпоху глобализации академическая мобильность обучающихся и преподавателей является неотъемлемой частью процесса интеграции высшего учебного заведения в Европейское образовательное пространство. В статье рассматривается академическая среда как важный фактор реализации международной мобильности студентов. Рассмотренные тенденции к открытой академической среде открывают новые возможности для академических обменов, которые в настоящее время предполагают сотрудничество, как с зарубежными вузами, так и с российскими. Следовательно, говорят о внешней и внутренней мобильности студентов и преподавателей, которая реализуется как на индивидуальном, так и на институциональном уровне. Таким образом, академические обмены можно рассматривать как средство развития и обновления образовательных программ высшего профессионального образования России. Это позволяет уйти от замкнутости российской системы образования, добиться признания образовательных программ, обеспечить прозрачность и признание компетенций и квалификаций, в целях повышения мобильности обучающихся, повысить конкурентоспособность российских образовательных программ на мировом рынке образовательных услуг. Проанализированный опыт международной деятельности СКФУ иллюстрирует теоретическую базу исследования, поскольку эмпирический материал четко структурируется в основные положения и требования к академической мобильности
UDC 378

Pedagogical science

\section{HIGHER SCHOOL ACADEMIC ENVIRONMENT AS THE REALIZING FACTOR FOR INTERNATIONAL STUDENT MOBILITY (experience of international activity of North Caucasus Federal University)}

Avakyan Ani Samvelovna

junior member of teaching staff

anichka35@mail.ru

Lomteva Tatiana Nikolaevna

Doctor of Pedagogical Sciences, Professor, Head of

Linguistics and Intercultural Communication

Department

North-Caucasian Federal University,

Russia, Stavropol

Under consideration is the international experience of NCFU in developing student mobility via French resource center. Today, in the era of globalization, student academic mobility is the integral part of the process of integrating higher education establishment into common European educational framework. Emphasis is made on the academic environment as an important factor of realizing international student mobility. Tendencies towards open academic environments set up new possibilities for academic exchanges both with foreign and Russian - based academic establishments. Thus, we can talk both about inner and outer student and teacher mobility, which is realized individually as well as on the institutional level. Conclusion is made that academic exchanges can be viewed upon as means of developing and renewing higher school educational programmers in Russia. This can eliminate exclusiveness of Russian educational system; pave the way for obtaining recognition of its educational programs; secure transparency and acknowledgment of competences and qualifications to raise student mobility and competition of Russian educational programs in the world market of educational services. The experience of NCFU in developing international activity discussed in the article illustrates the theoretical base of the research because empiric data well integrates into the framework of academic mobility 
ЗАКРЫТАЯ И ОТКРЫТАЯ АКАДЕМИЧЕСКАЯ СРЕДА, АКАДЕМИЧЕСКАЯ МОБИЛЬНОСТЬ, ВНУТРЕННЯЯ МОБИЛЬНОСТЬ, ВНЕШНЯЯ МОБИЛЬНОСТЬ, МЕЖДУНАРОДНАЯ ДЕЯТЕЛЬНОСТЬ, РЕСУРСНЫЙ ОБРАЗОВАТЕЛЬНЫЙ ЦЕНТР

Doi: 10.21515/1990-4665-133-066
AND OPEN ACADEMIC ENVIRONMENT, ACADEMIC MOBILITY, INNER MOBILITY, OUTER MOBILITY, INTERNATIONAL ACTIVITY, EDUCATIONAL RESOURCE CENTER

\section{Академическая среда вуза как фактор реализации международной мобильности студентов (из опыта международной деятельности Северо-Кавказского федерального университета)}

В настоящее время Российская система высшего профессионального образования ориентирована на интеграцию в Европейское образовательное пространство, что является необходимым условием и результатом Болонского процесса.

Основной причиной интеграционных процессов в сфере образования является требование предоставления возможностей профессиональной и личностной самореализации, повышение конкурентоспособности и мобильности специалистов. Благодаря академической и профессиональной мобильности, у студентов и преподавателей формируются такие компетенции как способность понимать и принимать другие культуры, уважение к многообразию, участие в языковом плюрализме. Одним из важнейших результатов академических обменов является расширение сотрудничества между вузами. Следует отметить, что каждый вуз самостоятельно определяет путь и способ реализации процесса интеграции в сферу высшего европейского образования.

Традиционно академическую среду определяют как «совокупность норм и правил общеобразовательной и научной деятельности, характерных для рассматриваемого сообщества, а также совокупность ресурсных, экспертных и статусных сетей, обусловленных этими нормами». Д.А. Александров считает, что «академическое сообщество существует сейчас в виде множества групп, ограниченных зачастую рамками одного 
университета. Они издают свои локальные журналы, руководствуются своими собственными, локальными стандартами и правилами» [1].

Академическая среда может быть как открытой, так и закрытой. Открытая академическая среда отличается высокой мобильностью преподавателей, а также магистрантов и аспирантов, которые поступают в иной вуз, а не в тот, где они получили степень бакалавра.

В рамках открытой модели университеты, в основном, не принимают на работу собственных выпускников. Таким образом, поддерживается система внешней оценки сотрудников, которые конкурируют на академическом рынке труда за места на факультетах престижных университетов.

Основным отличием закрытой среды от открытой является замкнутость соответствующего сообщества и локальность академических конвенций. Мобильность в такой среде воспроизводится в условиях низкой частотности. Закрытая среда характеризуется отсутствием миграции научно-преподавательского состава, горизонтальной академической мобильностью между образовательными и исследовательскими учреждениями. Сотрудники крайне редко меняют место основной работы, а вузы ориентированы на наем собственных выпускников. Научные связи, обмен преподавательскими практиками и студенческая мобильность развиты слабо или вообще отсутствуют [5].

Но происходящие в настоящий момент в мировом сообществе интеграционные процессы затрагивают как систему высшего образования в целом, так и закрытые академические среды, в частности.

На протяжении последних нескольких лет академической мобильности студентов, преподавателей, научных сотрудников и административного персонала вузов придается большое значение. Понимая выгоды, которые несет в себе развитие мобильности для роста конкурентоспособности вузов страны и развития общего рынка труда, 
руководители высших учебных заведений отмечают, что академическая мобильность стала неотъемлемой частью международной деятельности российских вузов, и что особенно важно - формирующим фактором их академической среды.

Берлинское коммюнике (2003 г.) объявило мобильность студентов и профессорско-преподавательского состава основой создания европейского пространства высшего образования [3]. Предоставление возможности получить разностороннее образование по выбранному направлению подготовки, расширение познания в области культуры являются основными целями мобильности.

Отметим, что академический обмен стал неотъемлемой частью международной деятельности российских вузов. Академическая мобильность в российских реалиях предполагает сотрудничество, как с зарубежными вузами, так и с российскими. Следовательно, можно говорить о внешней и внутренней мобильности студентов и преподавателей.

«Обучение студентов и аспирантов вуза в зарубежных вузах, а также работа преподавателей и сотрудников в зарубежных образовательных и научных учреждениях определяется как внешняя (международная) академическая мобильность» [7].

Внутренняя (национальная) академическая мобильность - это «обучение студентов и аспирантов, а также работа преподавателей и сотрудников вуза в ведущих российских университетах и научных центрах» [7].

К тому же, внешняя академическая мобильность существенно отличается от зарубежных стажировок тем, что студенты едут учиться за рубеж на ограниченный, но длительный срок (от семестра до учебного года), где они проходят полный семестровый или годичный курс, который им засчитывается по возвращении в вуз. 
В Болонском процессе выделяют 2 типа академической мобильности: «горизонтальную» и «вертикальную».

«Вертикальной мобильностью называют полное обучение студента на степень в вузе, горизонтальной - обучение там, в течение ограниченного периода (семестра, учебного года)». Одной из особенностей мобильности является непосредственное физическое перемещение субъектов мобильности, физическая мобильность не может быть заменена виртуальной [2].

Основываясь на опыте ведущих российских университетов [6] мы делаем вывод, что академическая мобильность реализуется в следующих организационных рамках:

- индивидуальная инициатива;

- организация совместных образовательных или исследовательских программ;

- программа исследовательских или научных грантов.

В настоящее время реализация совместных программ, которые будут способствовать модернизации технологии обучения и повышению качества образовательных программ, пользуется популярностью во многих российских вузах.

Интернационализация образовательного и научноисследовательского процесса, увеличение и расширение мобильности студентов и преподавателей принадлежит к числу приоритетных задач Северо-Кавказского федерального университета и является стратегически важным вектором развития вуза.

Основными задачами СКФУ в области международной деятельности являются:

- развитие экспорта образовательных услуг;

- развитие двустороннего сотрудничества и сетевого взаимодействия с ведущими университетами зарубежных стран; 
- интернационализация образовательной среды университета, а также реализация совместных образовательных программ, в том числе программ двойных дипломов;

- реализация программ академической мобильности студентов и преподавателей. С 2012 г. в программах академической мобильности приняли участие более 130 обучающихся и 130 сотрудников СКФУ. Ежегодно лекции во всех институтах СКФУ читают преподаватели из ведущих университетов мира [4].

Одним из успешных направлений по сотрудничеству в международной сфере стало взаимодействие СКФУ с Посольством Франции в Российской Федерации. В марте 2014 года в СКФУ был открыт ресурсный центр французского языка. Установление контактов, развитие партнерских отношений с французскими образовательными учреждениями, продвижение французского языка и культуры являются основными задачами центра. Деятельность центра курируется Посольством Франции в РФ и Французским институтом в РФ (Institut français de Russie).

Начиная с 2014, для преподавателей, студентов, аспирантов СКФУ и других учреждений города, лекторами-носителями французского языка проводится серия курсов, по дополнительным образовательным программам и по повышению квалификации:

- в 2014 г. аспиранткой Университета им. Блеза Паскаля (г. КлермонФерран, Франция) Шарлоттой Фон были проведены курсы «Основной курс французского языка (уровни А2, В1)», «Французский язык для детей», «Французский язык в сфере профессиональной деятельности»;

- в 2015 г. реализация дополнительной образовательной программы «Общий курс французского языка» (уровни В1, В2) лектором французского языка М. Л. Жесдоном; 
- в 2016 (второй семестр 2015-2016 уч. г.) реализация дополнительной образовательной программы «Дистанционные образовательные технологии в обучении французскому языку» лектором французского языка Т. Дуженом;

- $\quad$ в 2016 (2016-2017 уч. г.) реализация дополнительных образовательных программ лектором французского языка Т. Дуженом («Коммуникативная методика преподавания французского языка» и «Французский язык для специальных целей» (для аспирантов СКФУ).

- в 2017 г. реализация дополнительных образовательных программ: «Французский язык как средство межкультурной коммуникации» (уровни A1/A2); «Французский язык в сфере международного туризма»; «Французский язык для специальных целей» (уровни В1/В2) и программы повышения квалификации «Инновации в преподавании французского языка (опыт французской школы)» лектором французского языка Л. Мужен (магистрант Университета Пари Декарт (Франция) в области преподавания французского языка как иностранного), направленных на освоение французского языка и подготовку к международным экзаменам DELF/DALF [4].

Благодаря финансовой поддержке Посольства Франции в РФ и работе Ресурсного центра СКФУ, в вузе успешно и ежегодно реализуется совместная программа Французского института (Institut français) и Международного центра педагогических исследований (CIEP) «Ассистент преподавателя русского языка во Франции».

Начиная с 2014 г. эта программа академической внешней мобильности позволяет студентам работать во французских средних учебных учреждениях ассистентом преподавателя русского языка. Данный пост в разные годы занимали студенты СКФУ (2014-2015 уч. г. А. Авакян (г. Лилль); 2015-2016 уч. г. Н. Бенко (г. Клермон - Ферран) и А. Яйлоханова (г. Марсель); 2016-2017 уч. г. А. Магулаева (г. Гавр); 2017- 
2018 уч. г. Е. Нечепуренко (г. Версаль)). Основной функцией ассистента является улучшение коммуникативных компетенций учащихся и углублении их знаний о русском языке, литературе и культуре. Ассистент работает совместно с ведущим преподавателем русского языка в своем учебном учреждении.

Программа «Ассистент преподавателя русского языка во Франции» способствует увеличению студенческой мобильности на европейском и международном уровне, а также позволяет студентам получить дополнительные знания в области преподавания языков и первый опыт работы в сфере педагогической деятельности. Студенты получают возможность узнать язык и культуру Франции и поделиться в рамках своей работы в учебных учреждениях богатством русского языка и культуры.

Совместно с преподавателями ведущих языковых кафедр ресурсный центр французского языка ежегодно проводит мероприятия, целью которых является знакомство с культурой, историей, системой высшего образования Франции и франкоговорящих стран. Благодаря таким мероприятиям у обучающихся повышается уровень мотивации к изучению французского языка как средства межкультурного диалога:

- проект «Франкофутбол», запущенный Департаментом по сотрудничеству и культуре Посольства Франции в РФ;

- культурно-массовое мероприятие «Рождественские встречи»;

- международный семинар «Дни франкофонии в СКФУ»;

-неделя французского кино (просмотр аутентичных кинофильмов с субтитрами на французском языке) и др.

Таким образом, мы можем утверждать, что сегодня академическая мобильность становится нормой, а не исключением, а ее реализация и интеграция в академической среде являются важнейшей стратегической задачей каждого российского университета. 
Открытая академическая среда способствует развитию международной академической мобильности и увеличению конкурентоспособности российских студентов на международных рынках труда, что в значительной степени привлекает студентов из-за границы в Россию.

Опыт Северо-Кавказского федерального университета показывает, что академическая мобильность может быть реализована на следующих уровнях:

- на индивидуальном уровне - приобретение практических компетенций и навыков, необходимых для существования и профессиональной активности в условиях глобального рынка труда;

- на институциональном уровне академическая мобильность способствует распространению новых моделей администрирования, адаптации учебного процесса к требованиям международного рынка образовательных услуг.

Академические обмены становятся средством обновления и развития образовательных программ высшего профессионального образования России. Это позволяет уходить от замкнутости российской системы образования, плавно входить в европейское образовательное и научное пространство, что отвечает основным требованиям Болонского процесса и целям модернизации системы российского образования.

\section{Литература}

1. Александров Д.А. Почему советские ученые перестали печататься за рубежом: становление самодостаточности и изолированности отечественной науки [Текст] / Вопросы истории естествознания и техники, 1996, №3, с.3-24.

2. Берлинское коммюнике [Электронный ресурс]. - URL: http://www.russia.edu.ru/information/legal/law/inter/berlin/

3. Болонская декларация [Электронный ресурс]. - URL: http://www.russia.edu.ru/information/legal/law/inter/bologna/

4. Ресурсный центр французского языка Северо-Кавказского федерального университета [Электронный ресурс]. - URL: http://www.ncfu.ru/resursnyy-centrfrancuzskogo-yazyka.html 
5. Сивак Е.В., Юдкевич М.М. «Закрытая» академическая среда и локальные академические конвенции [Текст] / Форсайт, 2008, №4 (8), с. 32-41.

6. Современное состояние законодательно-правового обеспечения процессов внутренней и внешней академической мобильности студентов, аспирантов, преподавателей в Российской федерации [Электронный ресурс]. URL: http://www.acur.msu.ru/useful_basemobility.php

7. Харитонова О.В. Академическая мобильность в пространстве высшего образования [Текст] / Человек и образование, 2012, №2 (31), с.41-45.

\section{References}

1. Aleksandrov D.A. Pochemu sovetskie uchyonye perestali pechatat'sya za rubezhom: stanovlenie samodostatochnosti i izolirovannosti otechestvennoj nauki [Tekst] / Voprosy istorii estestvoznaniya i tehniki, 1996, №3, c.3-24.

2.Berlinskoe kommyunike [Jelektronnyj resurs]. - URL: http://www.russia.edu.ru/information/legal/law/inter/berlin/

3.Bolonskaya deklaratsiya [Jelektronnyj resurs]. - URL: http://www.russia.edu.ru/information/legal/law/inter/bologna/

4.Resursnyj tsentr frantsuzskogo yazyka Severo-Kavkazskogo federalnogo universiteta [Jelektronnyj resurs]. - URL: http://www.ncfu.ru/resursnyy-centrfrancuzskogo-yazyka.html

5. Sivak E.V., Yudkevich M.M. Zakritaya akademicheskaya sreda i local’niye akademicheskiye konventsii [Tekst] / Forsait, 2008, №4 (8), c. 32-41.

6. Sovremennoe sostoyaniye zakonodatel'no-pravovogo obespecheniya protsessov vnutrennej i vneshnej akademicheskoj mobil'nosti studentov, aspirantov, prepodavatelej $\mathrm{v}$ Rossijskoj federatsii [Jelektronnyj resurs]. - URL: http://www.acur.msu.ru/useful_basemobility.php

7. Kharitonova O.V. Akademicheskaya mobil'nost' $\mathrm{v}$ prostranstve vysshego obrazovaniya [Tekst] / Chelovek i obrazovaniye, 2012, №2 (31), c.41-45. 